\title{
Learning cycle 7E model to improve studying result and activity of IV grade students on natural science learning in SD Muhammadiyah Danunegaran of Yogyakarta
}

\author{
Irma Yulianti Budi Safitri a, ${ }^{\text {, Ika Maryani }}{ }^{\text {b, 2, * , Dwi Sulisworo }}{ }^{\text {c, } 3}$ \\ a SD Muhammadiyah Danunegaran, Indonesia \\ ${ }^{\text {b }}$ PGSD, Faculty of Teacher Training and Education, Universitas Ahmad Dahlan, Indonesia \\ c Physics Education Department, Faculty of Teacher Training and Education, Universitas Ahmad Dahlan, \\ Indonesia \\ 11irmabudi19@gmail.com, ${ }^{2}$ ika.maryani@pgsd.uad.ac.id *, ${ }^{3}$ sulisworo@gmail.com \\ * Corresponding author
}

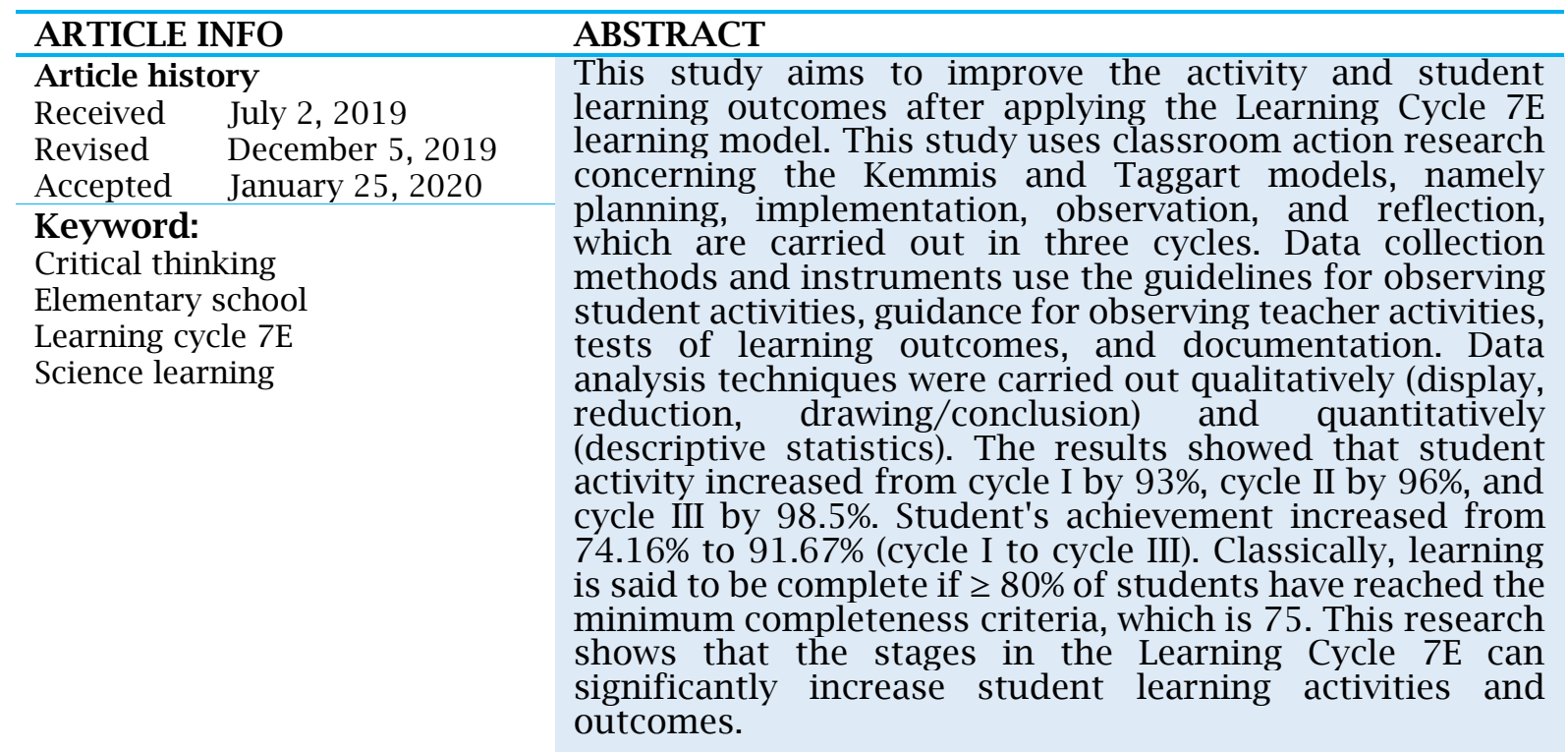

This is an open access article under the CC-BY-SA license.

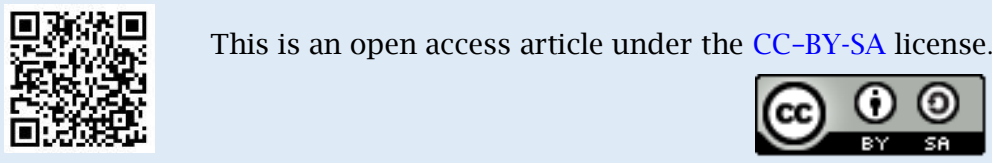

\section{Introduction}

Natural Science is one of the sciences with its object of study covers the natural environment around us. Natural Science learning in elementary school must be delivered empirically with the assumption that the universe can be studied, understood, and explained through a certain process, for instance: observation, experiment, and rational analysis (Kurniawan, Kardi, \& Tjandrakirana, 2016). Natural Science is not just focused on delivering subject or passing knowledge, but the student also must be active in using thinking skills in studying natural symptoms (Gani, 2018; Mulyasih, 2015). The teacher also must facilitate and create learning that can make students always active and curious (Setyosari, 2014).

Problems experienced by the student in learning Natural Science, namely, high complexity in learning Natural Science, cause student's comprehension concept is hard to be achieved (Mauke, Sadia, \& Suastra, 2013). Natural science teacher's pedagogic ability, especially in elementary school, still needs to be improved in order to be able to present meaningful natural science learning (Sudargo \& S Asiah, 2015). Natural science concept deliverance, which sometimes does not correspond with 
student characteristics, often causes difficulty in learning natural science (Fatimah \& Widiyatmoko, 2014; Maryani \& Amalia, 2018). Natural science learning that is still teacher-centered only focuses on passing knowledge, and the main purpose is to prepare students for the continuing study of higher level, not to prepare critical human resources, considerate to the environment, creative, and comprehend simple technology existing within the society (Rapi, 2016). Natural science learning tends to be a conventional activity that causes low studying outcomes. This condition requires treatment in creating effective natural science learning, especially on the elementary level, in order to achieve natural science essence as a process, product, and attitude (Yuliati, 2017).

Based on observation conducted on IV grade class in SD Muhammadiyah Danunegaran of Yogyakarta and interview with two teachers of IV grade class on August 2018, there are some identified problems in learning natural science as follows: (1) in the learning process, teachers still use learning method dominated with lecture, occasionally interspersed by discussion and task assignment, it is resulting students looks passively listening, noticing, and nothing of what was explained by the teachers. There it can see they were bored and saturated that causes students to become noisy or chattering with other classmates, (2) learning pattern still tends to be "textbook oriented" which means delivering lesson merely limited on what was written in the book, (3) the teachers have not utilized environment and using other media in teaching yet, only using the printed book as a primary resource in learning, (4) studying activity is low, it was indicated by students are less active in searching their own knowledge, tends to be passive and only waiting lesson from the teacher and also still counting on memorizing, (5) student's thinking is still low, one of the indicators is when the teacher asks a question, students took a long time to answer or even just still on silent and did not answer. This shows that students are not accustomed to being active in linking what was taught with new science and tends to wait for the answer from classmates or teacher's review. The students also rarely ask a question to the teacher or discussing the lesson. Student's involvements in learning are also still low. These problems can be overcome using a student-centered learning model, one of them is the learning cycle (Fatmawati, 2016).

The learning cycle is a learning model that is organized in such a way in order student can mastering their own competencies that are achieved according to the increased activity (Ngalimun, 2013). The learning cycle refers to a constructivist viewpoint in which knowledge is built on student's minds (Mecit, 2006). This learning model continues on development from 3 phase (3E) into 5 phase (5E) until becoming 7 phase (7E). This learning model of Learning Cycle 7E is developed by Arthur Eisenkraft in 2003. The learning model includes elicit phase (probing student's initial knowledge or understanding), engage (intriguing and focusing student's attention), explore (exploring or investigating), explain (explaining), elaborate (applying), evaluate (evaluating or assessing), and extend (expanding knowledge). Learning cycle implementation in learning assigns teacher as the facilitator that manages continuity of the phases starting from planning (especially learning device), implementation (especially giving directive questions and guidance process), and evaluation (Fajaroh \& Dasna, 2007).

Some of the success in applying the learning cycle in teaching among others can improve student activity and improve studying outcome, and can train student critical thinking skills (Kulsum \& Hindarto, 2011). Learning model application of Learning Cycle 7E in teaching makes students easier to comprehend a concept so that student's learning outcomes will be better (Agustin, 2018). Descriptive Learning cycle assisted by learning media can improve conceptual understanding and student critical thinking more optimum (Mulyasih, 2015). The learning model is also claimed to be very effective in enhancing interest, motivation, basic skill process, as well as natural science studying the outcome of elementary school pupils (Nurbani, Gusrayani, \& Jayadinata, 2016; Sole \& Wilujeng, 2013; Sugiantara, Kusmariyatni, \& Margunayasa, 2013). The success becomes a consideration of choosing Learning Cycle 7E as a solution to overcome natural science learning problems in SD Muhammadiyah Danunegaran. Based on the description above, hence this research aims to improve natural science learning activity and outcome using Learning Cycle 7E in IV grade students of SD Muhammadiyah Danunegaran. 


\section{Method}

\section{Research procedure}

This research was conducted to refer to Kemmis and Taggart (2006), which is through phases (1) planning, (2) implementation, (3) observation, (4) reflection conducted in cycles. Research is carried out in three cycles. Every cycle consists of 2 times meeting. With time allocation of $2 \times 35$ minutes (2 JP) every meeting. Phases in Learning Cycle $7 E$ are, elicit, engagement, exploration, explanation, elaboration, evaluation, extend.

\section{Subject and Object}

The research was conducted on IV grade students of SD Muhammadiyah Danunegaran during February-April 2019. The research subject was 24 students of IV grade consisted of 11 girls and 13 boys. Research object was study activity, which refers to indicator 1) answering questions, 2) ask questions or ideas, 3) working on an assignment and dare to step up in front of the class, and also 4) rebut or agree on other students' idea. Studying results with its indicator is adjusted by natural science learning indicator organism life cycle lesson.

\section{Data Collection}

The instrument in this research is divided into two instruments, which are a learning instrument and a data collection instrument. Learning instrument covers learning devices, namely: syllabus, Lesson Plan, Working Sheet, and evaluation question. At the same time, data collecting instrument covers learning outcome test question, observation sheet Learning Cycle $7 E$ implementation, and student's activity sheet. All of the data collecting instruments are validated by experts and specific learning outcome test questions using 15 essay questions, which have been validated externally by other students. Another instrument used in this research is learning video document that is used to find Learning Cycle 7E implementation success in other class. This video is very helpful for the researcher in reflecting the learning process at a time as additional data of observation results. The observer in this research is an associate (IV grade teacher) that has the same field as the researcher resulting in his justification can be accounted for.

\section{Data Analysis}

Data analysis in this research uses qualitative and quantitative data analysis. Qualitative data from observation result were analyzed using cycle model by Miles and Huberman with the display, reduction, drawing/conclusion phase whereas quantitative data of activity observation and test were analyzed using descriptive analysis with the following equation:

Activity score and studying result (Arikunto, 2015)

$$
\text { value }=\frac{\text { Score amount gain }}{\text { Maximum score amount }} \times 100
$$

The equation to calculate the completeness percentage is as follows:

Information:

$$
M=\frac{\sum X}{\sum N} \times 100 \%
$$

$\mathrm{P}$ : Completeness percentage of classical learning

$\Sigma \mathrm{X}$ : Students who achieve completeness $(\geq 75)$

$\Sigma \mathrm{N}$ : Entire student amount

\section{Completeness Criteria}

1) The research was said to be succeeded in learning process if student activity can achieve $\geq 80 \%$ success of all observed aspects.

2) The research can be said succeed if $80 \%$ of the students' amount has achieved minimum 75 score in the study outcome. The score is adjusted with MCC (Minimum Completeness Criteria) which is set up on natural science subject in SD Muhammadiyah Danunegaran.

\section{Results and Discussion}

Research findings and discussion on every aspect can be explained based on the Learning Cycle $7 E$ syntax sequence of every cycle. Observation on student's study activity with Learning Cycle $7 E$ showed that student's activity has not yet equally in all observed aspects, particularly in asking question aspects or ideas, and rebutting, and agreeing on other student's idea. However, the overall Learning Cycle $7 E$ implementation can make students active in studying. Observation finding on cycle I show that the lowest score in extends phase with a percentage of 72 percent and the highest score in elicit phase with the percentage of 96. Extend phase aims to make student think, search, find, and explain the example of concept application that has been studied and even this activity 
can stimulate student to look for concept's relation they studied with the other concepts in which they have or have not yet studied. This phase is considered difficult to implement compared to other phases in 7E. Teachers must encourage students to reflect on the knowledge they have or have not as well as linking it up with other concepts.

The activity average score on cycle I is as much as 93 with "very good" category. The outcome has proved the success of Learning Cycle 7E based on classical data considering completeness criteria for the activity aspect was 80 . Nevertheless, there are some students who its grade is still below MCC. This becomes consideration to carry on into cycle 2 . The aspect needs to be improved is on the aspect of asking question/idea.

In cycle 2, it occurred significant improvement in student's study activity classically. The highest score on the evaluation phase was 97 . Next in the second position with the highest score was on the elicit phase with 96 scores. The third place with the highest score was the exploration phase with 95 scores. Later on, the lowest gain was on the extension phase with 85 scores. Observation findings on cycle 2 showed average activity improvement of 96 with "very good" category. If it was compared with cycle activity average it means there was an improvement as much as 3.00 from cycle I. Student activity on cycle II was declared complete because it has fulfilled success criteria indicator which has set up by researcher, which is $\geq 80$. Nevertheless, implementation proceeds to cycle 3 to know student's activity completeness per phase of learning cycle $7 \mathrm{E}$.

In phase 3, the highest activity elicited and exploration phase with 97.50 score. In the elicit phase, teachers giving perception with discussion related to the given lesson. The teacher tries to arouse or bring in the student's initial knowledge. In this phase, the teacher can understand how far student's initial knowledge of the lesson will be studied by giving questions that can stimulate student's initial knowledge in the order it will arousing curiosity on the answer of questions given by the teacher. In the engagement phase, the teacher focuses on student's attention for their interest and curiosity about the topic studied by the relating question on factual in daily life. This phase gives a chance for the teacher to activate the learning; assessing student's initial knowledge, and make students share their initial experience on a topic. While on the exploration phase, students are divided into small groups in studying, then it was given the opportunity to cooperate within a group. The exploration phase allows students to build experience and knowledge as long they conduct investigation and observation. The role of the teacher in the exploration phase was as facilitator and motivator.

The second highest position was the evaluation phase with 96.5 scores. In the evaluation phase, the teacher observes or checks student's knowledge and observation on the lesson that has been studied. The teacher asked the question to evaluate them and the students answer, and also the teacher gives feedback to the students. In this phase, the teacher observes and notices student ability, and then the teacher saw changes in student thought toward initial thought.

The third highest position is the explanation phase with 95.50 scores. The explanation phase is a process in conception, processing, or skill so it can be comprehended, not to be doubted and clear. During this phase, students involved in the formulating exploration result conducted previously. The teacher acts as a facilitator in data processing techniques and books of observation results from the groups or the entire class. Information gathered during the exploration phase is discussed and listening to information with each other critically from classmates or teachers. The teacher helps the student to comprehend the science concept with easier language in the order it will easy to be understood by the student but the teacher also encourage the student to explain the concept with their own words. In this case, the teacher used the student's initial knowledge to explain the concept and to fix misconception occurs during engagement and exploration phase.

Based on the data above then it was derived average score as much as 98.50 with "very good" category. This is an improvement as much as 2.50 from cycle II. Activity on cycle III was declared completed because it had exceeded the success criteria percentage that is set up by the researcher. Which is 80 . Hence it can be concluded that student's activity had improved successfully, both in the process side or in percentage gained. Student's activity 
achievement on every Learning Cycle $7 E$ phase can be seen in Figure 1.

The Figure 1 show that there is a significant improvement in student's learning activity in natural science. Student's activity occurs during the implementation study was proved working that the Learning Cycle 7E studying model can succeed because of student, teacher, purpose, and studying method factor (Rahayuningsih, Masykuri, \& Utami, 2012). The student is the main component of learning. The student is a determinant in the learning-teaching process. The student must actively do, in learning it is the muchneeded activity; without it, the learning process would not run well.

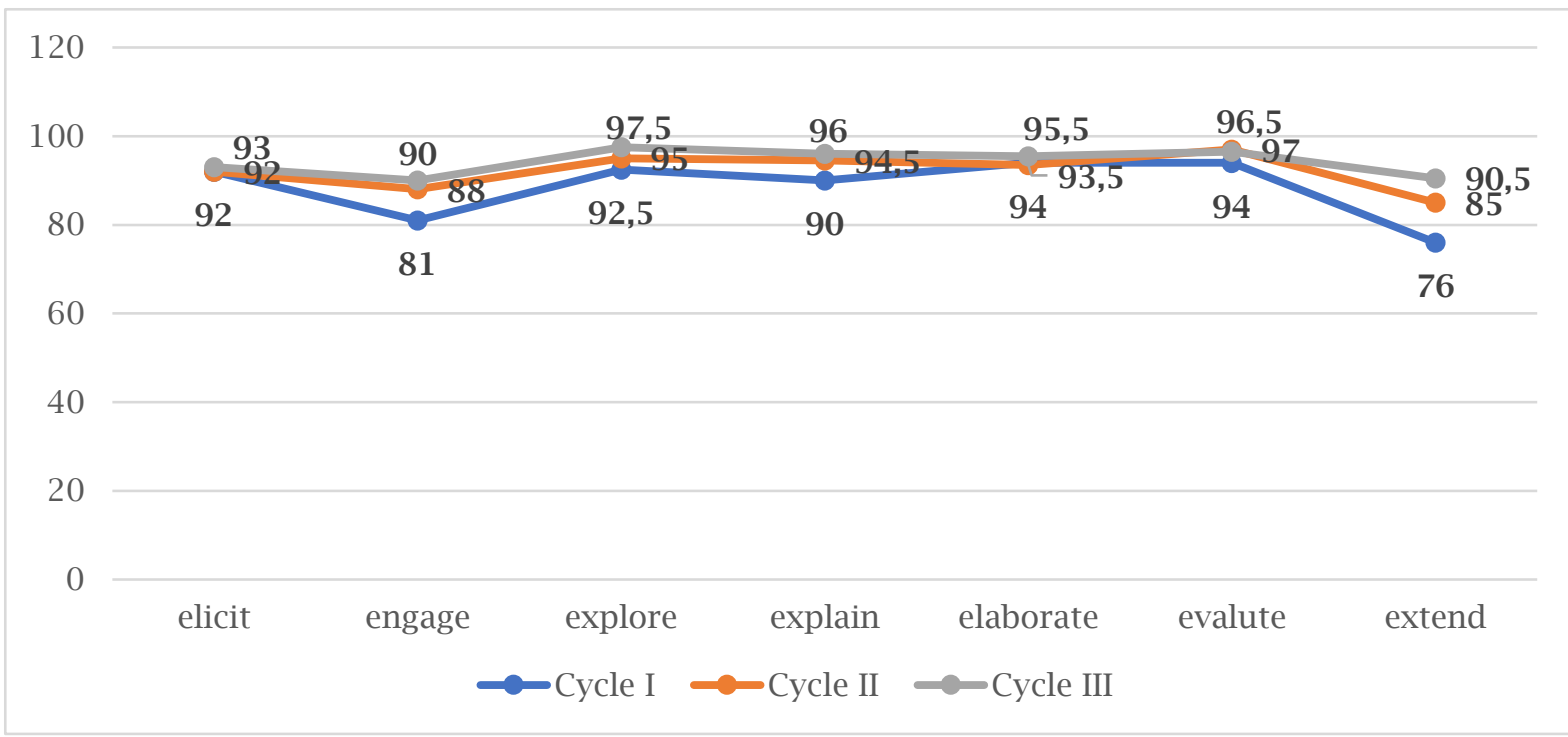

Figure 1. Student's activity percentage of cycle I-III

In the exploration phase, students make groups and every group working on Working Sheet. The student carried out observation collaboratively; students discussed and answered questions in Working Sheet. Students also directed to make a conclusion from the observation result and their discussion. Student's activity in the discussion, as well as student's skill to explore knowledge from experience derived, is an effort to increase student's thinking ability. Student's success in implement this phase positively affects studying motivation and student's scientific attitude (Muswahida, Subiki, \& Supriadi, 2015). This is because during the 7E phase, students are fully involved in solving problems collaboratively, resulting in they can respond to their group success. Learning Cycle $7 E$ also has a syntax that completely needs student's involvement. Therefore this model directly contributed positively to student activity improvement (Mirjanah, Hastuti, \& Priyayi, 2017). Learning Cycle $7 E$ is an improvement from the previous model, which is learning cycle $5 \mathrm{E}$, of which the difference is shown in Figure 2.

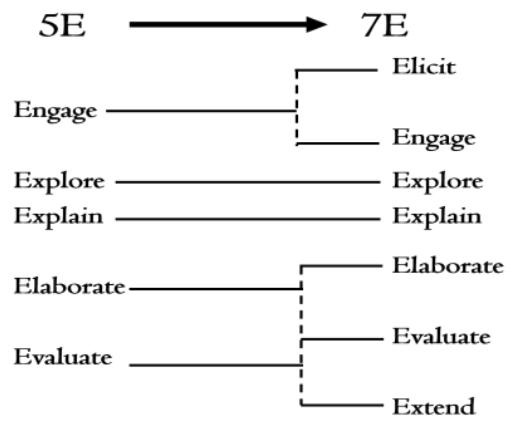

Figure 2.Phases changes in learning cycle 5E to 7E (Eisenkraft, 2003).

Some studies mentioned that Learning Cycle $7 E$ is more effective than $5 \mathrm{E}$ if it was viewed from the learning achievement aspect, creative thinking ability, and student's self-efficacy (Puspita, 2015; Riyandiarto, 2017). Implementation of Learning Cycle $7 E$ and 5E gives different impacts on high-level thinking skills (Nengsih, Susiswo, \& Sa'dijah, 2019). This is because component and learning phases in Learning Cycle $7 E$ is more facilitating student to develop thinking ability, particularly in elaborate, evaluate, and extend phase than 5E. 
On the study outcome aspect, Learning Cycle $7 E$ success is seen in the achieved target of every cycle. Figure 3 presents the assessment study outcome of the cycle I where it was found that 13 out of 24 students or $54.16 \%$ in grade IV of SD Muhammadiyah Danunegaran has gained score above MCC (75). While the rest (45.83\%) was declared not yet completed. The class average in cycle $\mathrm{I}$ is as much as 74.17. Based on set up completeness criteria as much as 75 in individually and $80 \%$ in classically, hence it was decided it must proceed on to cycle II.

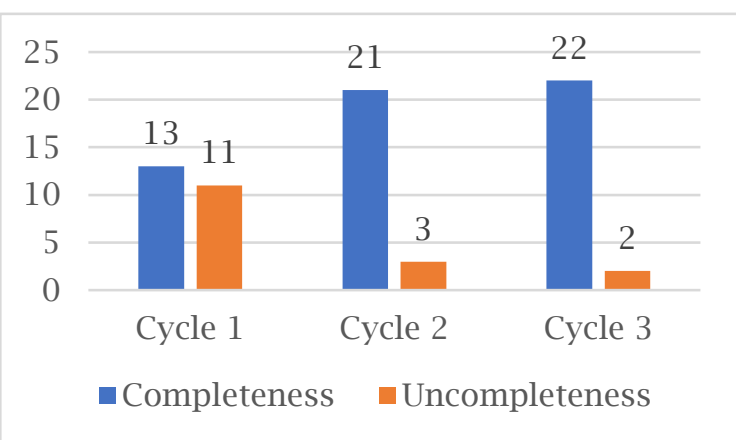

Figure 3.Student's study outcome completeness in cycle I-III

Study outcome assessment in cycle II, according to Figure 3, shows that 21 out of 24 students or $87.5 \%$ have gained scores above MCC. While as much as $12.5 \%$ has not achieved MCC yet. Students who are still deriving score below set up minimum criteria, with detail: one student gains 70 scores, and two students gain 65 scores. The average class reaches 84.38, and the classical completeness percentage is $87.5 \%$. Based on set up minimum completeness criteria are 75 and classically $80 \%$ then evaluation result on cycle II was declared completed. However, action will proceed to cycle III to achieve higher completeness.

Assessment in the study outcome of cycle III shows that 22 out of 24 students (91.67\%) have gained the study outcome above MCC. This means that student's study outcome in cycle III has exceeded the setup success indicator percentage score, which is $\geq 80 \%$. Therefore, the student's study outcome was declared complete and actions must be stopped. While 2 out of 24 students or $8.33 \%$ is still gain score below set up minimum completeness score, which is 60. The first student is a child with disabilities, and the other student was indicated as a slow learner since the beginning. Both of them take a long time to think, their comprehension of the lesson is less. It becomes the main reason for not achieved completeness study for both students.

The average class score reaches up to 84.58, and the classical completeness percentage reaches $91.67 \%$. The result in cycle III shows that the completeness indicator had achieved that it can be said study improvement outcome by implementing the Learning Cycle 7E model. Classical completeness can be seen in Figure 4.

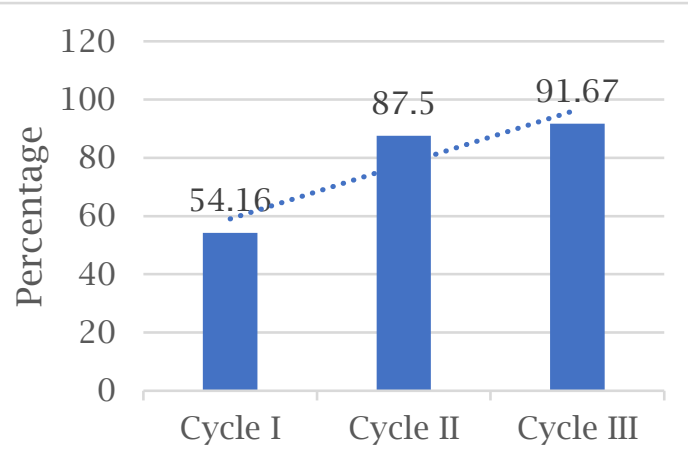

Figure 4.Classical completeness percentage of cycle I-III

Learning classical is said to be completed if $\geq 80 \%$ of students have exceeded MCC. Based on Figure 4, it can be known that classical completeness for the cycle I is as much as $54.16 \%$, cycle II is as much as $87.50 \%$, and cycle III is as much as 91.67\%. From cycle I-II, it occurs improvement as much as $33.34 \%$, and from cycle II-III also the same $4.17 \%$. Hence, based on individual completeness data and classical completeness percentage, it can be concluded that student's study outcome was increasing and declared succeeded according to success criteria that are set up by the researcher.

The study outcome improvement was influenced by various factors which are, student's activeness during 7E phases, improvement in personal and group responsibility, forming scientific attitude, and also increasing thinking skills. Thinking skills include critical or generic thinking skills (Adnyana, 2012; Irhamna, Rosdianto, \& Murdani, 2017; Latifa, Verawati, \& Harjono, 2017; Novianti, 2014; Sumarni, 2009). Improvement of thinking skills is conducted in every phase of 7E by fully involving the student to construct knowledge through problem-solving activity. This phase, at the same time, impacts directly to the teacher to master presented natural science concepts presented by the teacher. 


\section{Conclusion}

Based on the research findings and discussion above, it can be concluded that Learning Cycle 7E can improve the study outcome and activity of IV grade students in SD Muhammadiyah Danunegaran. The enhancement can be seen from successful action in indicator achievement from cycle I, II, and III on every measured aspect. The recommendation given is that Learning Cycle 7E should be completed with a medium that can objectify abstract concepts so that it makes it easier for pupils to comprehend the lesson. Moreover, Learning Cycle 7E requires a relatively long time in its implementation, so the researcher must be able to divide time allocation well in every phase. A lot of question exercises will also support student's concept comprehension with this method.

\section{Acknowledgement}

My sincere gratitude is to the Center of National Policy Analysis (Pusjaknas) Research Institution and Community Service Ahmad Dahlan University for assistance and financing while conducting research.

\section{References}

Adnyana, G. P. (2012). Keterampilan berpikir kritis dan pemahaman konsep siswa pada model siklus belajar hipotetis deduktif. Jurnal Pendidikan Dan Pengajaran, 45(3), 201-209. Retrieved from https://ejournal.undiksha.ac.id/ind ex.php/JPP/article/view/1833

Agustin, N. (2018). Penerapan model pembelajaran learning cycle 7E dalam pembelajaran IPA terpadu terhadap keterampilan proses sains siswa. Tadris: Jurnal Penelitian Dan Pemikiran Pendidikan Islam, 11(1), 1-10. Retrieved from http://ejournal.stitmatuban.ac.id/in dex.php/tadris/article/view/14

Arikunto, S. (2015). Dasar-dasar evaluasi pendidikan. Jakarta: Bumi Aksara.

Eisenkraft, A. (2003). Expanding the 5E model: A proposed 7E model emphasizes "transfer of learning" and the importance of eliciting prior understanding. The Science Teacher, 70(6), 56-59. Retrieved from https://www.jstor.org/stable/24156 091

Fajaroh, F., \& Dasna, I. W. (2007). Pembelajaran dengan model siklus belajar (learning cycle). Universitas Negeri Malang.

Fatimah, F., \& Widiyatmoko, A. (2014). Pengembangan science comic berbasis problem based learning sebagai media pembelajaran pada tema bunyi dan pendengaran untuk siswa SMP. Jurnal Pendidikan IPA Indonesia, 3(2), 146-153. Retrieved from https://journal.unnes.ac.id/ nju/index.php/jpii/article/view/31 14

Fatmawati, L. (2016). Peningkatan keaktifan dan pemahaman konsep IPS melalui model learning cycle 5E. Jurnal Prima Edukasia, 4(2), 148-162. https://doi.org/10.21831/jpe.v4i2.9 488

Gani, A. (2018). Pengembangan perangkat pembelajaran IPA SD/MI menggunakan inkuiri terbimbing untuk melatih keterampilan berpikir kritis siswa pada materi struktur tubuh. FONDATIA, 2(2), 168-171. https://doi.org/10.36088/fondatia. v2i2.132

Irhamna, I., Rosdianto, H., \& Murdani, E. (2017). Penerapan model learning cycle 5E untuk meningkatkan keterampilan berpikir kritis siswa pada materi fluida statis kelas VIII. Jurnal Fisika FLUX, 14(1), 61-64. https://doi.org/10.20527/flux.v14i 1.3839

Kemmis, S. (2006). Participatory action research and the public sphere. Educational Action Research, 14(4), 459-476. https://doi.org/10.1080/ 09650790600975593

Kulsum, U., \& Hindarto, N. (2011). Penerapan model learning cycle pada sub pokok bahasan kalor untuk meningkatkan keaktifan dan hasil belajar siswa kelas VII SMP. Jurnal Pendidikan Fisika Indonesia, $7(2), \quad 128-133 . \quad$ Retrieved from https://journal.unnes.ac.id/nju/ind ex.php/JPFI/article/download/1085 /995

Kurniawan, A. R., Kardi, S., \& Tjandrakirana, T. (2016). Pengembangan perangkat pembelajaran IPA berbasis pendekatan penemuan terbimbing 
untuk melatihkan keterampilan proses siswa sekolah dasar. Jurnal Review Pendidikan Dasar: Jurnal Kajian Pendidikan Dan Hasil Penelitian, 2(2), 175-183. https://doi.org/10.26740/jrpd.v2n2 .p175-183

Latifa, B. R. A., Verawati, N. N. S. P., \& Harjono, A. (2017). Pengaruh model learning cycle 5E (Engage, Explore, Explain, Elaboration, \& Evaluate) terhadap kemampuan berpikir kritis peserta didik kelas $\mathrm{X}$ MAN 1 Mataram. Jurnal Pendidikan Fisika Dan Teknologi, 3(1), 61-67. https://doi.org/10.29303/jpft.v3i1. 325

Maryani, I., \& Amalia, L. (2018). The development of science comic to improve student's understanding in elementary school. Jurnal Inovasi Pendidikan IPA, 4(1), 75-82. Retrieved from https://journal.uny. ac.id/index.php/jipi/article/view/2 1076

Mauke, M., Sadia, I. W., \& Suastra, I. W. (2013). Pengaruh model contextual teaching and learning terhadap pemahaman konsep dan kemampuan pemecahan masalah dalam pembelajaran IPA-Fisika di MTS Negeri Negara. Jurnal Pendidikan Dan Pembelajaran IPA Indonesia, 3(2). Retrieved from http://119.252.161.254/e-journal/ index.php/jurnal_ipa/article/view/7 96

Mecit, Ö. (2006). The effect of 7E learning cycle model on the improvement of fifth grade students' critical thinking skills (Middle East Technical University). Retrieved from http://etd.lib.metu.edu.tr/ upload/12607661/index.pdf

Mirjanah, M., Hastuti, S. P., \& Priyayi, D. F. (2017). Peningkatan aktivitas dan hasil belajar siswa melalui penerapan model learning cycle 7E (LC 7E) pada pembelajaran biologi kelas X IPA 4 SMA Negeri 1 Bringin tahun pelajaran 2016/2017. Jurnal VARIDIKA, 29(1), 18-27. https://doi.org/10.23917/varidika.v 29i1.5146

Mulyasih, S. S. (2015). Model pembelajaran siklus belajar deskriptif untuk meningkatkan pemahaman konsep dan keterampilan berpikir kritis siswa SMK pada materi ikatan kimia. Jurnal Pengajaran MIPA, 20(1), 5359. https://doi.org/10.18269/jpmip a.v20i1.563

Muswahida, V., Subiki, S., \& Supriadi, B. (2015). Penerapan model learning cycle $7 \mathrm{E}$ berbantu alat peraga tiga dimensi (3D) terhadap sikap ilmiah dan hasil belajar siswa Pada pembelajaran fisika kelas X SMA. Jurnal Pembelajaran Fisika, 4(3), 219-223. Retrieved from https://jurnal.unej.ac.id/index.php/ JPF/article/view/2640

Nengsih, L. W., Susiswo, \& Sa'dijah, C. (2019). Kemampuan pemecahan masalah matematika siswa sekolah dasar dengan gaya kognitif field dependent. Jurnal Pendidikan: Teori, Penelitian, Dan Pengembangan, 4(2), 143-148. Retrieved from http://journal.um.ac.id/index.php/j ptpp/article/view/11927

Ngalimun. (2013). Strategi dan model pembelajaran. Yogyakarta: Aswaja Pressindo.

Novianti, A. (2014). Pengaruh model pembelajaran learning cycle terhadap keterampilan berpikir kritis siswa. EDUSAINS, 6(1), 109116. Retrieved from http://journal. uinjkt.ac.id/index.php/edusains/art icle/view/1105

Nurbani, D., Gusrayani, D., \& Jayadinata, A. K. (2016). Pengaruh model learning cycle terhadap keterampilan proses sains siswa SD kelas IV pada materi hubungan antara sifat bahan dengan kegunaannya. Jurnal Pena Ilmiah, 1(1), 211-220. Retrieved from https://ejournal.upi.edu/index.php /penailmiah/article/view/3301

Puspita, W. R. (2015). Perbandingan keefektifan model learning cycle 5E dan 7E dalam pembelajaran bangun ruang sisi datar ditinjau dari prestasi belajar, kemampuan berpikir kreatif, dan self-efficacy siswa Sekolah Menengah Pertama (Universitas Negeri Yogyakarta). Retrieved from https://eprints.uny. ac.id/25850/

Rahayuningsih, R., Masykuri, M., \& Utami, B. (2012). Penerapan siklus belajar 5E (Learning Cycle 5E) disertai peta konsep untuk meningkatkan 
kualitas proses dan hasil belajar kimia pada materi kelarutan dan hasil kali kelarutan kelas XI IPA SMAN 1 Kartasura tahun pelajaran 2011/2012 (Universitas Sebelas Maret). Retrieved from https://digilib.uns.ac.id/dokumen

Rapi, N. K. (2016). Pengaruh model pembelajaran dan jenis penilaian formatif terhadap hasil belajar IPA siswa SMPN. Jurnal Cakrawala Pendidikan, 35(1), 69-79. https:// doi.org/10.21831/cp.v1il.8366

Riyandiarto, B. B. (2017). Efektifitas model learning cycle $5 \mathrm{E}$ dan $7 \mathrm{E}$ dalam pembelajaran turunan fungsi ditinjau dari prestasi belajar siswa SMA kelas XI. Jurnal MathGram Matematika, 2(2). Retrieved from https://ejournal.unugha.ac.id/index .php/mthg/article/view/174

Setyosari, P. (2014). Menciptakan pembelajaran yang efektif dan berkualitas. JINOTEP (Jurnal Inovasi Dan Teknologi Pembelajaran) Kajian Dan Riset Dalam Teknologi Pembelajaran, 1(1), 20-30. https://doi.org/10.17977/um031v1 i12014p020

Sole, F. B., \& Wilujeng, I. (2013). Pengaruh implementasi the 4-E learning cycle terhadap pengetahuan, keterampilan proses dasar, dan sikap ilmiah IPA siswa SDK Kererobbo. Jurnal Prima Edukasia,
1(1), 43-50. https://doi.org/ 10.21831/jpe.vli1.2315

Sudargo, F., \& S Asiah, S. (2015). Kemampuan pedagogik calon guru dalam meningkatkan kemampuan berpikir kritis dan keterampilan proses siswa melalui pembelajaran berbasis praktikum. Jurnal Pengajaran Matematika Dan Ilmu Pengetahuan Alam, 15(1), 4-12. https://doi.org/10.18269/jpmipa.v $15 \mathrm{i} 1.287$

Sugiantara, I. P., Kusmariyatni, N., \& Margunayasa, I. G. (2013). Pengaruh model pembelajaran learning cycle 5E terhadap hasil belajar IPA siswa kelas V di gugus VII kecamatan Buleleng. MIMBAR PGSD Undiksha, 1(1). Retrieved from https://ejournal.undiksha.ac.id/ind ex.php/JJPGSD/article/view/673

Sumarni, W. (2009). Penerapan learning cycle sebagai upaya meningkatkan keterampilan generik sains inferensial logika mahasiswa melalui perkuliahan paktikum kimia dasar. Jurnal Inovasi Pendidikan Kimia, 4(1), 521-531. Retrieved from http://journal.unnes.ac.id/nju/inde x.php/JIPK/article/download/1309/ 1381

Yuliati, Y. (2017). Literasi sains dalam pembelajaran IPA. Jurnal Cakrawala Pendas, 3(2), 21-28. https://doi.org/ 10.31949/jcp.v3i2.592 